\title{
I, a Girl Who is New to the World of English Academic Writing
}

\author{
Wei Luo ${ }^{1}$ \\ Writing across the University of Alberta, $2021^{2}$ \\ Volume 2, pp. 17-20 \\ Published December 2021 \\ Keywords: academic writing, learning English as an additional language, religious studies
}

The magical realizations and enlightenments in my mortal life generally do not happen with signs like rainbow clouds showing up in the sky or lotus petals leading me onto an adventure path. Most of them happen after my professors ask to talk with me. And not to lie, I have had quite a bit of talk ever since I started university.

It was a -35 Celsius degree winter school day, a typical school day for anybody who studies at the University of Alberta or the University of North Pole. My professor, who was teaching me Introduction to Christianity, asked me to come to his office to discuss my paper.

Old St. Joseph College needs to renovate its heaters for the basement. When I was sitting inside my professor's office, listening to him talking about how unpolished my ideas were, I felt super cold. Professor Zelyck, a top-notch biblical scholar who sure knows his business, has memorized at least a hundred of both contemporary and early commentaries of the Nicene Creed. ${ }^{3}$ Of course, he did draw me a handwritten list with the help of his brain instead of the all-mighty Google and said, "Go read these, and you will be fine," with his kindly Canadian accent. I said, "Thank you, Professor," while thinking: "wait, what, did he remember all those by heart? Who are you? Are you Elijah, the miracle worker?" This was perhaps the first moment when I had a clear picture of what it is to be a good scholar.

I began wondering what made up a good scholar: a Ph.D.? Or a solid amount of publications? In order to feed my craving for answers, I started my journey to ask as many

\footnotetext{
${ }^{1}$ Correspondence: Wei Luo (wluo4@ualberta.ca)

${ }^{2}$ Writing across the University of Alberta (WAUA) publishes undergraduate student writing from Writing Studies courses at the University of Alberta. You can find WAUA online at writingacrossuofa.ca.

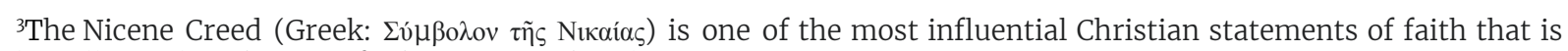
broadly used in Christian faith service such as liturgy.
} 
professors of mine about their origin stories as academics. The answers were varied and sometimes conflicted with each other. Still, they all seemed to lead to three significant clues for my question: the ability to research one subject, examine materials, and, most importantly, the ability to deliver one's ideas within one paper.

\section{'Unpick the Complexity into Simpleness'(化繁为简/Hua Fan Wei Jian)}

As a person who has never received any systematized English training, my English writing ability was terrible. Back in the first year, when I got into the $U$ of $A$, my academic school life was like a 5-cent supermarket paper bag appointed to contain dangerous chemical goods for a lab, and I am talking about things like sodium cyanide. In other words, I did not feel like I could even handle papers, let alone write a good one. But I sure love my major, religious studies, and am willing to bug my professors as much as I can so that I can survive in the field and find some success.

Through the charity English writing training given by my professors, who are actually teaching me Buddhism studies and classical theories of religions, I began to enter a minor stage of Nirvana (a Hindu idea of enlightenment). This is just a fancy way of saying that I realized that the contents matter the most in an academic paper. I began to write as straightforwardly as I could, for I remembered Professor Quinter once said to me, "if you can show your understanding of Shingon Buddhism to seven-year-old children and successfully make them understand, then you made it to the highest stage of a Religious Studies scholar." It was perhaps what Taoism refers to as 'unpick the complexity into simpleness'(化繁为简 /Hua Fan Wei Jian).

Although my case is not like that; I do not have the ability to deliver the message with more complex writing, and my pen cannot write as precisely and luxuriously as a native English writer. Still, I say, I have entered the gate of English academic writing ever since then. In my view, non-native English writers should try to become good writers rather than perfect writers when they just start to write in English.

\section{Breaking the Taboo in My Mind}

Good research work includes many things, and in my field of Religious Studies, it involves encountering and examining as many relevant materials as one can. The core of this matter is that scholars in Humanities can never go further without the collected wisdom from the people who came before them and their peers.

In the field of Writing Studies, scholars have been discussing the uniqueness of academic readings for a long time. Scholars such as John C. Bean, Virginia A. Chappell, and Alice M. Gillam suggest that "Academic reading has unique demands and pleasures," and 
doing those readings is like listening to logical debates that require readers to observe and critique in particular ways (2-5). Very often, students in my field will have to read more than a thousand claims from different scholars on one subject before writing a 3000-word research paper. Thus, while unpacking the tangling issues on a controversial topic, one can often find that scholars from different fields or even from the same field disagree with each other. It is even unlikely that everybody would agree on one approach. When I realized this, my mind completely changed, for I realized the fact that there are not that many universal truths and that disagreements in academia happen more often than I think. I was liberated because my writing sometimes can be controversial or non-mainstream, and it freed my pen from the fear of disagreeing with others who are more knowledgeable than I am. After I broke the taboo, I actually gained more respect for the world of academics, for it is filled with competition but is always inclusive of conflicts and different opinions.

\section{The Love Potion From A Midsummer Night's Dream}

As a student writer who fears having my peers read my papers deeply, I always want to meet the forest fairies and get some purple flower juice to put on my classmates' eyes so that they are going to love my papers blindly. But since I could never find the fairies' business number, I asked the university's Centre for Writers instead. Most of the tutors there don't have pointy ears, but their degrees in English and Film Studies seem very convincing to me.

All of my writing tutors had mentioned to me that a good writer should know how to communicate with their readers, and the critical point is to make sure the writer has an idea of their audience before starting to write. Perhaps the love potion for writing is to write the contents that the targeted audience might like, or even just try to give the pieces to the right audience.

Once I received this information, I began to do experiments as any good humanities student would. I started by communicating with my peers from my classes first to see what interested them in the class, what kinds of topics spoke to them the most and what they would say about my previous papers. For sure, I do feel like a clout chaser while doing it. Still, preparation activity like this actually ensures that I will explain certain contents that others are unfamiliar with, will give me inspiration for topics, and most importantly, help me to develop a writing style that is more understandable to others. As a Chinese student from China, I received a very different education than most of my Canadian peers, which means that my writing style is foreign, and some of my punchlines in papers might seem artificial or confusing to them. For example, I will always have to explain my jokes related to Eastern Asian folk cultures in my writing, which kills the fun part of making jokes, but it sure clears the clouds for my audience when they are reading my compositions. 
Professional speech trainer Sheila Heen argues in her presentation "How to use others' feedback to learn and grow" that many people have learned about giving feedback from life but have not learned much about receiving feedback (2:04- 2:39). In my view, it echoes my experiments of trying to get feedback for my previous papers and listening to the preferences of my peers in advance of writing a new paper that is going to be reviewed by them. Thus, I suggest other non-native English writers do the same activity before their writing, and it is likely that they will be able to have a clear picture of the audience while writing. They might even be able to deliver ideas more clearly to their audience.

\section{Speaking in Tongues}

Civilizations are often associated with different languages, and the brightest works of each civilization are often passed down through written accounts. When I stand before tremendous ancient pieces of literature and literature of my time, the desire to understand these works has made me become a better reader. The beauty of knowledge and literature encourages me to develop skills in my second language ability, for I am the smallest sand on the beach of human civilization, but I dare to be able to leave some words for the world I love when I leave. The countries of Earth are now closer than ever, but I know that in turns of cultural exchanges, most of us are just like the scene of "speaking in tongues" 4 : we gather together but cannot understand each other. Throughout my paper, I elaborated on what kind of enlightenment made me become a better second language student writer. Still, the biggest motivation that carries me on this path is my dream to communicate with more people, and the hope is when they read my works, it will not be like "speaking in tongues" anymore.

\section{Works Cited}

Bean, John C., Virginia A. Chappell, and Alice M. Gillam. Reading Rhetorically. 4th ed. Pearson, 2014.

Heen, Sheila. How To Use Others' Feedback To Learn and Grow. YouTube, uploaded by

TEDxAmoskeagMillyardWomen, Jun 22, 2015, https://youtu.be/FQNbaKkYk_Q.

\section{(c) $(9)$ This work is licensed under CC BY-NC-ND 4.0. To view a copy of this license, visit}

\footnotetext{
${ }^{4}$ Speaking in tongues is also known as glossolalia. In the Christian belief system, it is viewed as a practice in which people speak languages unknown to the speaker; people can tell that the speaking is fluently speaking a language, but no one can understand it.
} 